\title{
SHAPING THE MEMORY OF THE FRENCH WARS OF RELIGION. THE FIRST CENTURIES
}

\author{
Philip Benedict
}

In 1683, the historian Louis Maimbourg dedicated his Histoire de la Ligue to Louis XIV with some reflections about the past century. ${ }^{1}$ Although France was now a unified kingdom capable of dictating terms to the entire globe, he wrote, it had almost been destroyed in the sixteenth century by 'two baneful leagues of rebels'. 'Heresy formed the first against the true religion; ambition disguised as zeal gave birth to the second'. Mercifully, divine providence subsequently granted the house of Bourbon the glory of triumphing over both of these leagues. First Henry the Great defeated the 'League of False Zealots (Ligue des Faux-Zelez)' with his valour and his clemency. Then Louis the Just disarmed the Calvinists by capturing the strongholds in which they had established a form of rule contrary to monarchical sovereignty. Finally Louis the Great, through his combination of charity, zeal for the conversion of the heretics, and concern for the just application of the law, reduced the Protestant party to so weak a condition that its end seemed nigh.

Maimbourg's depiction of the later sixteenth century as a time of two baneful leagues reminds us that the history of how later generations recalled and passed along the story of the French Wars of Religion is a particularly complex one not merely because so many specific episodes of trauma, from local ambushes to larger massacres to political assassinations shook families, localities and the kingdom over nearly forty years of conflict, but also because the conflicts involved two different insurgent parties in two different phases with two different outcomes. The party whose emergence was central to the initial conflicts, the Protestant party, survived every threat to its existence and gained renewed legal recognition at every peace. The party whose emergence was central to the conflicts of the later phase, the Catholic League, was decisively defeated in what can be called the War of the Bourbon Succession from 1589 to 1598 . Since

\footnotetext{
${ }^{1}$ Louis Maimbourg, Histoire de la Ligue (Paris, 1683), 'épitre au roi'.
} 
the former group was present as a legally recognised religious minority from 1598 to 1685 and would live on even after the Revocation, each side in the initial Protestant-Catholic conflicts had descendants who judged it important to keep alive their side of a story that engendered dramatically divergent perceptions, justifications and memories. The League, however, had no posterity eager to transmit a positive account of its history across the generations. Many of its most committed members went into exile. Those who stayed in France and made their peace with Henry IV had a strong interest in seeing their prior opposition to the founder of the new ruling dynasty forgotten. Memories of this phase of the civil wars would be far less contested.

In the case of the French Wars of Religion, the tension between memory and forgetting present in all post-civil-war or post-regime-change situations was also distinctively shaped by the emphasis on oubliance in the peace-making efforts of the era. From the edict of pacification that ended the first civil war in 1563 through the Edict of Nantes, every edict of pacification that brought another civil war to an end enjoined those who had just been fighting one another to consider everything that happened in the prior tumults 'extinguished and as if they were dead, buried and had never happened', and to refrain from suing or provoking one another on account of what had happened. ${ }^{2}$ These amnesty clauses were meant chiefly to prevent lawsuits or vendettas arising from events of the justconcluded war, but contemporaries also understood them to set limits to what published historical works could recall. Two edicts of pacification, the 1576 and 1577 peaces of Beaulieu and Bergerac also forbade specific memorial practices, notably processions held to commemorate the death of the prince of Condé, Saint Bartholomew's Day, 'and other acts that might revive the memory of the troubles'. ${ }^{3}$ An explicit legal obligation if not to bury this era of the past in silence then at least to be very careful not to write, say or do anything about it that might provoke offense or discord thus remained in force from 1598 to 1685 .

Oubliance, however, had its limits - three important limits in particular. First, the terms of the Edict of Nantes based the rights of assembly of many local Protestant churches on the fact of their having regularly gathered at specific dates during the Wars of Religion. Disputes about or verification of these churches' right to exist led inexorably to appeal to the

2 André Stegmann (ed.), Édits des guerres de religion (Paris: Vrin, 1979), passim, esp. 36.

3 Stegmann (ed.), Édits des guerres de religion, 109, 143. 
historical record. Second, confessional identity and confessional rivalry were powerful antidotes to historical amnesia. For each side, recalling the hostile actions of the other reminded members of the community of the importance of continued vigilance and of the emptiness of the rival faith's claim to be the true Christian church. Third, the growing interest in the history of both the nation and the ruling dynasty during these centuries of early modern state-building, together with the fact that certain events simply could not be avoided in any coherent attempt to tell the story of the local or national community, ensured that historical examination of this period never ceased. And since the imperatives of critical history advanced among the learned as the century advanced, the manner in which these events were told became increasingly constrained by respect for documentary evidence and its critical evaluation. These last developments pulled the memory of the Protestant-Catholic conflict in a different direction from that encouraged by the ongoing confessional rivalry.

\section{The Initial Civil Wars and the Catholic-Protestant Struggle}

From the Conspiracy of Amboise in 1560 onward, France's 'troubles of religion' gave rise to rival stories of victimisation, vindication and deliverance through divine protection on either side of the confessional rift. The Protestants were the first to publish histories of these events in abundance, probably because, as a minority movement accused from the $1530 \mathrm{~s}$ onward of being seditious, they felt particularly compelled to justify their actions and to defend themselves against the charge of sedition. Their histories took many forms: the martyrologies that Jean Crespin and his continuators began to produce regularly from 1554 onward; short histories of specific events designed to spin them favourably for the cause; compilations of pamphlets and manifestos of which the Mémoires de l'estat de France sous Charles neufiesme (1576-1577) and the Mémoires de la Ligue (numerous instalments from 1587 to 1599 ) were the most copious and important; longer accounts of specific periods constructed on the model of Johann Sleidan's Commentaries on the State of Religion and Public Affairs under Charles V by Pierre de La Place (1565) and Louis Regnier de La Planche (1576); the collaborative ecclesiastical history of the first years of the Reformed churches in France published in 1580; and finally the fulldress histories of Lancelot Voisin de La Popelinière (1581) and Agrippa d'Aubigné (written between 1595 and 1612; published between 1616 and 1620). Although these histories often copied entire passages from one 
another, they did not agree on every detail of the stories they recounted. With the exception of La Popelinière, who self-consciously aimed to write a non-partisan account of these years 'as the good historiographer should do', they nonetheless all presented the Protestants as the victim of unceasing and illegitimate attempts to exterminate them who, when they had taken up arms, had only done so to protect themselves and the king against unlawful attempts by ambitious members of the clan of Guise to subvert royal authority and undo the toleration granted them in January $1562 .{ }^{4}$ This representation of the past quickly became a fundamental building block of Huguenot identity and political self-understanding, even if after 1620 few additional Protestant histories of the years 1560-1598 made their way into print. ${ }^{5}$ This is because the accounts of the massacres and civil wars drawn from the histories of religion and public affairs were integrated into later editions of the Acts of the Martyrs, which in turn became a staple of both individual and collective reading in French Protestant households, the most widely owned book after only the Bible and the Psalter. ${ }^{6}$ The influence of this initial corpus of early Huguenot histories also came to be felt beyond the Protestant community since these works were characterised by ample circumstantial detail and a strong concern to document their assertions through the direct citation of purportedly authentic records. This would impress later generations of historians of all perspectives. ${ }^{7}$

4 The literature on Huguenot historical writing is abundant. See in particular André Thierry, Agrippa d'Aubigné, auteur de l'histoire universelle (Lille: Service de reproduction des thèses, 1987); Jean-François Gilmont, Jean Crespin, un éditeur réformé du XVIe siècle (Geneva: Droz, 1981); Philip Benedict, Graphic history. The wars, massacres and troublesof Tortorel and Perrissin (Geneva: Droz, 2007), 125-129 and the works cited there; and Amy Graves-Monroe, Post tenebras lex. Preuves et propagande dans l'historiographie engagée de Simon Goulart (1543-1628) (Geneva: Droz, 2012). Huguenot historiography, memory and identity across the centuries was also the subject of a major conference held at Ascona, Switzerland in October 2010, the acts of which, edited by Philip Benedict, Hugues Daussy and Pierre-Olivier Léchot, are scheduled to appear in 2013 in the Publications de l'Association Suisse pour l'Histoire du Réfuge Huguenot under the title L'identité huguenote. Faire mémoire et écrire l'histoire (XVI $-X X I^{e}$ siècles). I have been able to draw with profit on many of the communications presented there.

5 Elisabeth Labrousse, 'Les guerres de religion vues par les Huguenots du XVII e siècle', in Philippe Joutard (ed.), Historiographie de la Réforme (Neuchâtel: Delachaux et Niestlé, 1977), 37-44.

6 One Huguenot household in eight owned a copy according to a sample of post-mortem inventories from seventeenth-century Metz. Philip Benedict, 'Protestant and Catholic book ownership in seventeenth-century Metz', in his The faith and fortunes of France's Huguenots, 160o-85 (Aldershot: Ashgate, 2001), 173, 188.

7 Henri Hauser, Les sources de l'histoire de France. XVIe siècle (1494-1610), 4 vols. (Paris: A. Picard, 1906-15), vol. 3, 14. 
Catholic historians were slower to respond with histories of their own, more given to invective, and less concerned to document their assertions with the same appearance of care. Nevertheless, beginning with Claude de Sainctes' 1562 Discourse on the sacking of Catholic churches by the ancient and the new Calvinist heretics, quickly published in six editions between Paris, Verdun, Toulouse and Avignon, Catholics too produced histories and martyrologies that highlighted the subversive and violent actions of the Protestants, dwelled in pornographic detail on the torture of clergymen and the desecration of sacred objects, and hailed the Catholic champions who had preserved the faith. ${ }^{8}$ Also beginning amid the first civil war of $1562-1563$, Catholic authorities initiated commemorative processions to recall their deliverance from Huguenot takeover attempts or their liberation after a period of Protestant occupation.

When one compares the great majority of Catholic and Protestant histories of this period, one finds little common ground between them. Each side recalls its own victimisation and the other's violence. Accounts of the same event diverge sharply. A small number of chronicles of these years may nonetheless be situated at some sort of midpoint between the most partisan historians on both sides. For instance, the 'Short discourse and memoir of certain events in Normandy and France since the beginning of the year 1559, chiefly in Rouen', probably written by the Rouen canon Jean Nagerel, deplored the loss of life on both sides and found nothing to celebrate in the recapture of the city by the royal and Catholic forces in

8 This Catholic historiography has never been studied as a whole. Important works include Claude de Sainctes, Discours sur le saccagement des églises catholiques, par les hérétiques anciens, et nouveaux calvinistes, en l'an mil cinq cens soixantedeux (Paris and Verdun, 1562, Paris, 1563, Toulouse and Avignon, 1564, Paris, 1567, 1587); Pierre Belon, 'Cronique', published by Monica Barsi as L'énigme de la chronique de Pierre Belon. Avec édition critique du manuscrit Arsenal 4651 (Milan: LED, 2001); Georges Bosquet, Hugoneorum haereticorum Tolosae coniuratorum profligatio (Toulouse, 1563; French transl. Toulouse, 1595); Loys de Perussiis, Discours des guerres de la Comté de Venayscin et de la Provence: ensemble quelques incidentz, (Avignon, 1563; Antwerp, 1564, 1565); Loys de Perussis, Le second discours des guerres de la Comté de Venayscin (Avignon, 1564); Gabriel de Saconay, Discours des premiers troubles avenus à Lyon, avec l'Apologie pour la ville de Lyon, contre le libelle faussement intitulé: "La Juste et sainte défense de la ville de Lyon" (Lyon, 1569); Henri Hauser, 'Un récit catholique des trois premières guerres de religion. Les Acta Tumultuum Gallicanorum', Revue Historique 108 (1911), 59-74, 294-318; 109 (1912), 75-84; Jean Le Frere de Laval, La vraye et entiere histoire des troubles et guerres civiles, avenues de nostre temps pour le faict de la religion, tant en France, Allemagne que païs bas (Paris, 1573, 1574, 1575, 1576, 1578, 1582); 'De Tristibus Galliae', published by Léon Cailhava as De Tristibus Franciae Libri Quatuor (Lyon: Louis Perrin, 1840); François de Belleforest, Les grandes annales et histoire générale de France (Paris, 1579); Mémoires de Claude Haton, 4 vols. (Paris: Comité des Travaux historiques et scientifiques, 2001-07). 
October $1562 .{ }^{9}$ A moderate or moyenneur historiographic tradition also quickly took shape, albeit in a minor key. ${ }^{10}$

The edicts imposing oubliance and the urgency the crown felt to enforce them in certain times and places limited the circulation of the more partisan histories, especially on the Catholic side. A Catholic history of the Huguenot attempt to take over Toulouse in May 1562 that was published soon after the 1563 pacification edict of Amboise and that particularly offended against the principle of oubliance by naming the names of those who fought on both sides and by dwelling on the 'cruelties, indignities and barbarous acts' of 'the faction of Huguenots and Calvinists, miserable offspring of Luther' was immediately banned by the Conseil du Roi. All copies were ordered destroyed.11 Thereafter, partisan Catholic histories chiefly found their way into print from presses outside the kingdom in such places as Avignon, Turin and Antwerp or during periods when Protestant worship was not tolerated in France. Most Protestant histories were also published outside France, in Geneva, but its active presses and steady flow of men and books back and forth to France made it easier for the Protestants to get around the restrictions governing what might be said within the kingdom. The Protestants thus not only beat the Catholics to the punch in terms of writing extensive, well-documented histories in a manner concordant with their view of events; they got a higher percentage of their most important histories into print. While barred from print, however, partisan Catholic chronicles recalling Huguenot treachery, sacrilege and violence circulated in manuscript, as their textual history and citation in later local histories shows. ${ }^{12}$

9 Alexandre Héron (ed.), Deux chroniques de Rouen (Rouen and Paris: Société de l'Histoire de Normandie, 1900); Philip Benedict, 'Deux regards catholiques sur les premières guerres de religion à Rouen', in Jean-Pierre Poussou and Isabelle Robin-Roméro (eds.), Histoire des familles, de la démographie et des comportements en hommage à Jean-Pierre Bardet (Paris: Presses de l'Université Paris-Sorbonne, 2007), 735-740.

10 Another work in this key is Jean Philippi, 'Histoire des troubles de Languedoc, 156o16oo', published by Louise Guiraud, La Réforme à Montpellier, vol. 2, Preuves (Montpellier: Mémoires de la Société Archéologique de Montpellier, 1918).

11 Recueil de pieces historiques relatives aux guerres de religion de Toulouse (Paris: A. Abadie, 1862), 3 .

12 For evidence of the circulation of manuscript histories and how they were used, see Julien Blauf, Issoire pendant les guerres de Religion, ed. André Serre (Clermont-Ferrand: La Française d'Édition et d'Imprimerie, 1977), 11-20; L'invasion de la ville du Mans par les religionnaires en l'année mille cinq cens soixante et deux (Le Mans, 1667); Hilary J. Bernstein, 'Réseaux savants et choix documentaires de l'histoire locale française. Écrire l'histoire de Bourges dans la seconde moitié du XVII e siècle', Histoire Urbaine 28 (2010), 65-84, esp. $79-80$. 
In cities with a significant Huguenot presence, the clauses of edicts of pacification prohibiting Catholic commemorative processions were also generally applied to keep tension between the two communities from sparking violence, but in overwhelmingly or exclusively Catholic cities that had witnessed some form of Huguenot threat during the civil wars, they often were not. Here, such ceremonies lived on for centuries. Processions recalling a foiled Huguenot siege, 'surprise', or 'escalade' formed a regular part of the ceremonial year throughout much or all of the Ancien Régime in eleven cities that have been identified to date, and more cases surely remain to be discovered. ${ }^{13}$ These rituals regularly mobilised the participation of the local civil and ecclesiastical elites. They often included sermons recalling the event in question and warnings of the dire consequences that would follow if the plague of heresy contaminated the city again. The largest drew crowds of spectators estimated in the tens of thousands. They were thus powerful collective instruments for keeping alive stories of the danger that the Protestants had once posed to the community and might do again if not carefully controlled. ${ }^{14}$

In some of the same cities, the Catholic memorial tradition emphasising victimisation and deliverance was also passed along through paintings in the town hall recalling the city's resistance to a Protestant siege (as in Poitiers and Chartres) or local legends recalling how at a key moment in the fight against the Huguenots the Virgin or the patron saint of the city had come to its aid (as in Chartres, Verdun and Le Mans). ${ }^{15}$ Material

13 Philip Benedict, 'Divided memories? Historical calendars, commemorative processions, and the recollection of the Wars of Religion during the Ancien Régime', French History 22 (2008), 392, to which list can now be added the case of Auxerre.

14 André Sanfaçon, 'Légendes, histoire et pouvoir à Chartres sous l'Ancien Régime', Revue Historique 279 (1988), 337-357; André Sanfaçon, 'Evénement, mémoire et mythe. Le siège de Chartres de 1568', in Claire Dolan (ed.), Evénement, identité et histoire (Sillery Que.: Éditions du Septentrion, 1990), 187-204; Pascal Julien, “Assaut, invocation tutélaire et célébrations séculaires. Le 17 mai 1562 'delivrance de Toulouse' ", in Gabriel Audisio (ed.), Prendre une ville au XVIe siècle (Aix-en-Provence: Publications de l'Université de Provence, 2004), 51-62; Hilary Bernstein, Between crown and community. Politics and civic culture in sixteenth-century Poitiers (Ithaca: Cornell University Press, 2004), 179; Stefano Simiz, 'La mémoire catholique d'un échec protestant à travers les siècles. La tentative de surprise de Verdun en septembre 1562', Annales de l'Est 59 (2009), 129-139; Olivier Christin, 'Mémoire inscrite, oubli prescrit. La fin des troubles de religion en France', in Reiner Marcowitz and Werner Paravicini (eds.), Vergeben und Vergessen? Vergangenheitsdiskurse nach Besatzung, Bürgerkrieg und Revolution (Munich: Oldenbourg Verlag, 2009), 81-84.

15 Benedict, Graphic history, 110-111 and plates 5 and 6; Sanfaçon, 'Légendes, histoire et pouvoir à Chartres', esp. 347; Benedict, 'Divided memories?', 394-395; [Claude Blondeau?], L'invasion de la ville du Mans par les religionnaires en l'année mille cinq cens soixante et $\operatorname{deux}($ Le Mans: Louis Peguineau, 1667), 64. This last work also reveals that by the second 
objects could also testify to past events. An explosive device that failed to go off properly after the Protestants had planted it by a city gate in their effort to capture Le Puy by surprise in 1585 stood on display in that city's cathedral for generations. ${ }^{16}$

Even in cities that lacked public rituals of commemoration, other vectors perpetuated a Catholic martyrological tradition in clerical milieus and among some laymen. The Augustinian monastery in Lyon contained a painting depicting a prominent member of the order being flayed alive during the 1567 massacre of Catholics in Nimes, the Michelade. ${ }^{17}$ The hagiographic work of the friar Saint Martin, The Life of Saint Augustine and of several saints of his order (Toulouse, 1641), told the same story in print. ${ }^{18}$ A pious work in a different genre, the father Archange de Clermont's Jerusalem's Mount Calvary transported to France by the piety of a Dauphiné Catholic (Lyon, 1638), surprisingly includes a detailed account of the harassment of clergymen and confiscation of church property in Romans during the First Civil War based on solid research in the municipal registers from the period of Huguenot domination. ${ }^{19}$ Well into the eighteenth century, local histories dwelled at length on Protestant plots against the city or the violence and misery that accompanied periods of Huguenot domination. ${ }^{20}$

The Protestant counterpart to commemorative processions would have been the action de graces or thanksgiving ceremony, but no evidence has yet been found of a regular celebration of this sort in a Protestant stronghold in France comparable to Geneva's fête de l'Escalade or England's Guy Fawkes Day - which is not to say that further research might not uncover some. As the minority faith, however, the Reformed rarely controlled the public spaces and public rituals. During the seventeenth century, their martyrological and self-justificatory tradition survived chiefly

half of the seventeenth century these legends were beginning to be viewed with skepticism by the local learned elites. This phenomenon would become yet more marked in the eighteenth century.

16 Bruno Maes, Le roi, la Vierge et la nation. Pèlerinages et identité nationale entre guerre de Cent Ans et Révolution (Paris: Publisud, 2002), 138n.

17 Léon Ménard, Histoire civile, ecclésiastique et littéraire de la ville de Nismes, 7 vols. (Paris: Hugues-Daniel Chaubert, 1750-58), vol. 5, Notes, 4.

18 Ibid., vol. 5, Notes, 4.

19 Jules Chevalier (ed.), Mémoires du Pere Archange de Clermont pour servir à l'histoire des Huguenots à Romans 1547-1570 (Romans: R.S. André, 1887).

20 For a late example of a very common phenomenon: Calendrier historique de la ville de Lyon pour l'an de grace 1726 (Lyon, s.a.), 234-238 and Calendrier historique de la ville de Lyon pour l'an de grace 1727 (Lyon, s.a.), 239-264. 
in the intimacy of the community. The historical calendars printed for inclusion in many seventeenth-century Psalters reminded the faithful of major episodes of the Wars of Religion and especially of the massacres that had been the cause's lot. ${ }^{21}$ The abundant papers of the Metz minister Paul Ferry show that he devoted many studious hours to collecting information about the community's early history that could be drawn upon by the church's spokesmen if needed to defend its right of assembly. ${ }^{22}$ The reading notes of another pastor from later in the seventeenth century show him paying particular attention to the Book of Martyrs' account of the Saint Bartholomew's massacre and writing in the margin alongside its estimate of 30,000 killed 'or 100,000' ${ }^{23}$ Most tellingly, when at the approach of the Revocation, the political context in which the edicts of pacification had been granted and the history of the French Reformation more generally became a subject of intense public debate between Catholic and Protestant historians, the positions defended by the Protestants cleaved to exactly the same lines as those defended by the earliest selfjustificatory histories of the movement. ${ }^{24}$

Such would no longer be the case by the later seventeenth century among learned Catholic historians. While the martyrological, self-justificatory and commemorative traditions continued to be perpetuated in hagiography, in legends and in the public rituals of certain cities, an alternative view of the Wars of Religion had taken shape by this time among many of the most authoritative Catholic historians and their readers. This view depicted these conflicts as arising not from the seditious and sacrilegious actions of the heretics, but from the rivalry between the greatest noble families of the day, the overweening ambition of the house of Guise, and the character flaws of other key political actors, most notably Catherine de Medici.

At the fountainhead of this tradition stood the towering figure of Jacques-Auguste de Thou, who took as the primary lesson of his 3,400-page History of his own time that attempts to uproot heresy by banishment or

21 Benedict, 'Divided memories?', 388-389.

22 Julien Léonard, 'Histoire, mémoire et identités réformées chez Paul Ferry', forthcoming in Philip Benedict, Hugues Daussy and Pierre-Olivier Léchot (eds.), L'identité huguenote. Faire mémoire et écrire l'histoire (XVIe-XXIe siècles) (Geneva: Droz, forthcoming).

23 Philip Benedict, 'The owl of Minerva at dusk. Philippe Le Noir de Crevain, a pastorhistorian under Louis XIV', Faith and Fortunes, 255.

24 Philip Benedict, 'La conviction plus forte que la critique. La Réforme et les guerres de religion vues par les historiens protestants à l'époque de la Révocation', forthcoming in Benedict, Daussy and Léchot (eds.), L'identité huguenote. 
burning never worked, but instead only intensified people's commitment to their religious opinions and sparked wars that enabled the minority faith to reinforce its numbers and power. Written from a politique perspective in the wake of the League in which the Guises had so clearly played a leadership role, it had no difficulty accepting what had previously been the partisan Protestant view that the ambition and treachery of the house of Lorraine had been the chief cause of the early troubles as well. Sympathetic to toleration rather than concerned with justifying Catholic violence against Protestantism, it often relied upon early Huguenot histories. It broke with the prior Catholic historical tradition by recounting in detail the popular violence following Saint Bartholomew's day and even hinting that the massacre, which it clearly deplored, might have been premeditated. The extensive research on which it was based and its masterful Latin style, not to mention its sheer bulk, gave the work enormous authority. To suggest that the civil wars were born out of aristocratic rivalry, monarchical weakness and errors of policy-making, of course, was to imply that a country could live in peace even if it contained two religions so long as factionalism was brought to heel and a stronger crown pursued wiser policies. ${ }^{25}$

In the wake of De Thou, other leading historians such as Enrico Davila, François Eudes de Mézeray and Antoine Varillas also wrote essentially political narratives of this period whose accounts of individual events stood somewhere between those offered in the earlier, more partisan Protestant and Catholic accounts. Whereas the first Catholic histories to touch on the Saint Bartholomew's massacre presented it as a wholly justified response to previous Calvinist plotting and violence, these histories generally deplored the extent of the killing and made heroes of those local authorities who kept their city from re-enacting the Parisian bloodbath. ${ }^{26}$

25 Jacques-Auguste De Thou, Histoire universelle, 11 vols. (The Hague, 1740), esp. vol. 1, xlii-xlvii. De Thou's historical work still awaits an adequate treatment. I hope to explore his depiction of the Wars of Religion and its influence on the subsequent historiography of the subject further in future essays.

26 Enrico Caterino Davila, The history of the civil wars of France (London, 1678); François de Mézeray, Histoire de France, 3 vols. (Paris, 1685), vol. 3, esp. 1-3, 740-751; Antoine Varillas, Histoire de Charles IX (Paris, 1683). For the broader context of historical writing in seventeenth-century France and biographical information about these authors: Blandine Barret-Kriegel, Les historiens et la monarchie 4 vols., (Paris: Presses Universitaires de France, 1988); Orest Ranum, Artisans of glory. Writers and historical thought in seventeenth-century France (Chapel Hill: University of North Carolina Press, 1980); Steve Uomini, Cultures historiques dans la France du XVII e siècle (Paris: Harmattan, 1998); Christophe Blanquie, Un magistrat à l'âge baroque. Scipion Dupleix (1569-1661) (Paris: Publisud, 2008). 
By the latter half of the century, the new political vision of the civil wars was sufficiently powerful for substantial elements of it to be integrated into Bossuet's lessons for the dauphin; the history that the future bishop of Meaux dictated to his princely pupil even incorporated into its account of the Saint Bartholomew's massacre the story of Charles IX shooting at fleeing Protestants from a window of the Louvre, a purported detail of the event first recounted in the radical Protestant Reveille-matin des François and repeated by Mézeray. ${ }^{27}$ Not all prominent seventeenth-century Catholic historians accepted the broad interpretation of the late-sixteenthcentury conflicts as first and foremost aristocratic civil wars. Scipion Dupleix, writing during the 1620 s and 1630 s, explicitly defended the view that the conflicts were above all wars of religion and stressed that the Protestants were the first to begin the cycle of tit-for-tat violence and war crimes that marked the period. ${ }^{28}$ In the historical controversies of the era of the Revocation, a series of Catholic historians likewise reiterated the responsibility of the Calvinists for each new cycle of the civil wars in order to make the case that it was just to end the toleration of this inherently seditious heresy. ${ }^{29}$ Yet when these latter historians took up specific episodes of the troubles, they no longer narrated them as their sixteenthcentury predecessors had done. For instance, where previous generations of Catholic historians asserted baldly that the conspiracy of Amboise aimed to seize the king and overthrow the monarchy, the historians of this generation admitted that the evidence concerning the goals of the

Wilfred Evans, L'historien Mézeray et la conception de l'histoire en France (Paris: J. Gamber, 1930); Antoine Varillas, Les anecdotes de Florence, ou l'histoire secrète de la maison des Médicis ed. Michel Bouvier (Rennes: Presses Universitaires de Rennes, 2004), Introduction.

27 Régine Pouzet (ed.), Charles IX. Récit d'histoire par Louis Dauphin et Bossuet (ClermontFerrand: Adosa, 1993), 47, 239. On the place of the story of Charles IX's firing on the Huguenots in the memory of the massacre, see Philippe Joutard, Janine Estèbe, Elisabeth Labrousse and Jean Lecuir, La Saint-Barthélemy ou les résonances d'un massacre (Neuchâtel: Delachaux et Niestlé, 1976), 66, 105, 110-117, 153; Philip Benedict and Barbara Diefendorf, 'Religionskriege: Bartholomäusnacht', in Pim den Boer et al. (eds.), Europäische Erinnerungsorte, 3 vols. (Munich: Oldenbourg Verlag, 2012), vol. 2, 403-412.

${ }^{28}$ Scipion Dupleix, Histoire générale de la France, 3 vols. (Paris, 1644), vol. 3, esp. 568.

29 Louis Maimbourg, Histoire du Calvinisme (Paris, 1682); Pierre Soulier, Histoire des Édits de pacification et des moyens que les P.R. ont emploés pour les obtenir, contenant ce qui s'est passé de plus remarquable depuis la naissance du Calvinisme jusqu'à présent (Paris, 1682); Pierre Soulier, Histoire du Calvinisme, contenant sa naissance, son progrès, sa décadence, et sa fin en France (Paris, 1686); Jacques-Bénigne Bossuet, Histoire des variations des Eglises protestantes (Paris, 1688). See also Elisabeth Israels Perry, From theology to history. French religious controversy and the Revocation of the Edict of Nantes (The Hague: Martinus Nijhoff, 1973); Alfred Rebelliau, Bossuet historien du protestantisme (Paris: Hachette, 1891). 
conspirators was contradictory. ${ }^{30}$ Increased respect for documentary evidence and critical methods had reduced the degree of divergence between Catholic and Protestant accounts of the same events.

\section{The Memory of the Catholic League}

Since, as has already been suggested, the memory of the Catholic League was less contested, there is less to be said about it. Once Henry IV converted to Catholicism and secured the allegiance of the different League chieftains and cities, the dominant historical interpretation of what had just transpired was quickly fixed. As the first important historian of this conflict, the Protestant convert to Catholicism Pierre Palma Cayet, wrote, the war of the League had been 'a war for the state and not a war for religion'. ${ }^{31}$ The overweening ambition of the house of Guise had been the principal cause. Spanish and papal meddling had exacerbated the situation. If Catholic zeal entered into the equation, it was a false or deformed zeal. 'All forms of zeal are not good,' he wrote; 'the Holy Scriptures do not approve of those that are ill considered, extravagant and desperate'. ${ }^{32}$ The view first set forth in Palma Cayet's Chronologie Novenaire of 1608 and in the later chapters of De Thou's History of His Own Time still structured understanding of this era when Maimbourg sat down to write his Histoire de la Ligue on the eve of the Revocation. ${ }^{33}$ One dissenting history is known. Probably written by a Parisian robin around 1620, it downplayed foreign intervention and emphasised the concern of the movement's founders to defend the Catholic faith and the principle that the king of France must profess it. But it was never published, although it was preserved in the library of the Oratorians in Paris, where scholars might have consulted it. ${ }^{34}$

30 Maimbourg, Histoire du Calvinisme, 127; Soulier, Histoire du Calvinisme, 18.

31 Pierre-Victor Palma Cayet, Chronologie novenaire (Clermont-Ferrand: Paleo, 2007), 23.

32 Ibid., 24. See also Ann W. Ramsey, Liturgy, politics and salvation. The Catholic league in Paris and the nature of Catholic reform 1540-1630 (Rochester: University of Rochester Press, 1999), chpt. 4.

33 A brief overview of how successive epochs viewed the League is Marco Penzi, “'Damnatio memoriae'. La 'Ligue catholique française' e la storiografia, tra 'politiques', rivoluzionari, mistici e liberali", Quaderni Storici 118 (2005), 263-284.

34 'Histoire de la Ligue', Bibliothèque nationale de France, mss Fonds Français 2329523296; Charles Valois (ed.), Histoire de la Ligue, oeuvre inédite d'un contemporain (Paris: Renouard, 1914), esp. viii; see also Paul Fournier's review of this edition, Bibliothèque de l'École des Chartes 76 (1915), 169. 
With the League generally disgraced and stigmatised, the less said about it the better most Catholics agreed, especially those descended from erstwhile Leaguers or attached to cities that had adhered to it. Seventeenth- and eighteenth-century local histories of former League strongholds regularly adopted the stance of Auxerre's Symphorien Le Beuf, who wrote that the city had sought to bury the era of League domination in eternal forgetfulness by destroying all of the archival documents concerning it, so he would do the same. ${ }^{35}$ Three generations of the Ruffi family of Marseille wrote histories that examined the period of the League in which their family had been deeply implicated. The descendants of the first generation buried their role in silence. Two generations later LouisAntoine de Ruffi claimed that they had sided against the League. ${ }^{36}$

What was most frequently recalled about this period was opposition to the League, Henry IV's skill in overcoming it, and the rallying to his banner in the wake of his conversion. When, early in the eighteenth century, an annual guide to Lyon's courts, government and trade fairs included instalments tracing successive eras in the city's history, the instalment devoted to the years 1568-1599 raced through the period of the League, asserting that it was not necessary to speak of the misfortunes of the time since they were common to the entire kingdom. It then highlighted that as soon as Lyon learned that Henry IV had embraced Catholicism, it recognised him as its rightful king, becoming the first major city to do so. As Paris had led the way to revolt, Lyon led the way to obedience. ${ }^{37}$ Paris, Dijon and Avallon held annual processions to recall the moment when they recognised the authority of the first Bourbon and opened their gates to him, while Senlis, a rare bastion of fidelity to Henry of Navarre in a region otherwise dominated by the League, commemorated the city's successful resistance against a siege by the forces of the Sainte-Union in $1589 .{ }^{38}$ Dijon's city council also met in a room whose inscriptions recalled

35 Quoted in Claire Dolan, 'L’identité urbaine et les histoires locales publiées du XVIe au XVIII ${ }^{\mathrm{e}}$ siècle en France', Canadian Journal of History 17 (1992), 284. Hilary Bernstein, who is currently researching local histories of the period 1560-1660, tells me that neglect of the period of the League is recurrent in the histories she has examined from this period.

36 Wolfgang Kaiser, 'Le passé refaçonné. Mémoire et oubli dans les Histoires de Marseille, de Robert Ruffi à Louis-Antoine de Ruffi', Provence Historique 193 (1998), 279-292.

37 Calendrier historique de la ville de Lyon pour l'an de grace 1728 (Lyon: André Laurens, s.a.), 286-287. The same boast appears in Claude de Rubys, Histoire véritable de la ville de Lyon (Lyon, 1604), 450.

38 Benedict, 'Divided memories?', 393; Michel Cassan, 'Conclusion', in Michel De Waele (ed.), Lendemains de guerre civile. Réconciliations et restaurations en France sous Henri IV (Quebec City: Presses de l'Université Laval, 2011), 256; Thierry Amalou, Le Lys et la Mitre. 
several mayors who had opposed the League and secured the city's return to obedience to its rightful king. ${ }^{39}$ Processions commemorating the end of the League nonetheless seem to have been considerably less common than those recalling a city's deliverance from an attempted Protestant takeover.

For politique Catholics, the League was also worth recalling as an object lesson in the dangers of excessive clerical intervention in politics. One notorious episode encapsulated this message: the 1590 parade of clergymen and students armed to defend Paris under siege in the course of which one gun-toting friar accidentally shot a member of the papal legate's entourage. Numerous painted and graphic versions of this Procession of the League are known, several of which drive the message home with the Lucretian inscription 'Tantum religio potuit suadere malorum' (to such evil are men driven by religion). So popular was this image that a character in Agrippa d'Aubigné's 1630 Les Aventures du Baron Faeneste speaks of having 'seen these paintings in all the great houses' and asks the baron to acquire one for him. ${ }^{40}$ Seventeenth-century re-printings of the Satyre Ménippée also made members of the learned elite familiar with its burlesque account of the 1593 Estates General. Seventeenth-century Protestant historical calendars noted episodes such as the Sorbonne's call to refuse obedience to Henry III after the killing of the duke and cardinal of Guise. ${ }^{41}$ Come the eighteenth century and Voltaire's enormously influential epic the Henriade, these events, and the history of the League more generally, would assume a still larger place in the national memory, now as a synecdoche not for the dangers of false zeal, but of zeal tout court.

To conclude, forgetting was much easier when one side in a conflict had been definitively defeated than when its descendants remained to preserve and defend their understanding of a contested past, and indeed

\footnotetext{
Loyalisme monarchique et pouvoir épiscopal pendant les guerres de Religion (1580-1610) (Paris: Éditions du CTHS, 2007), 352-356, 449.

39 The former council chambers are today the reading room of the Archives Départementales de la Côte-d'Or, where the inscriptions can still be seen.

40 Cited in Tom Hamilton, “The 'procession de la Ligue'. Parisian processions and their representation toward the end of the wars of religion", unpublished paper. I have relied heavily on this paper for my discussion of this image and wish to thank Mr. Hamilton for sharing his research with me. Paintings of the Procession de la Ligue may be found in the Musée Carnavalet in Paris, the Musée de l'Histoire de France in Versailles, and the Musée des Beaux-Arts of Rouen. For engraved versions see G. Duplessis, Inventaire de la collection d'estampes relatives à l'histoire de France, leguée en 1863 à la Bibliothèque Nationale par Michel Hennin, 5 vols. (Paris: Menu, Picard, Champion, 1877-84), nos. 1033-1038.

41 Benedict, 'Divided Memories?', 383, 405.
} 
had quickly produced a large, well-documented corpus of histories about the subject. Despite the clauses of oubliance, starkly polarised rival views of the Protestant-Catholic conflicts of the Wars of Religion were preserved in many histories and martyrologies of both sides, in the public rituals and iconography of certain overwhelmingly Catholic towns, in Catholic legend, and in Huguenot historical calendars. From the turn of the seventeenth century onward, however, the sharply polarised rival historical accounts of both parties that dwelled overwhelmingly on the evils done to their camp were increasingly challenged and partially displaced by ones that emphasised personal rivalries and poor political decision-making as the causes of conflicts and that moved the narrative of events toward a common ground that owed a great deal to the earliest Protestant accounts of events. The story of the League was far less contested and changed less over time. There was simply nobody to defend the cause nor any authoritative published histories transmitting an alternative view. 